\title{
PENGEMBANGAN LEMBAR KEGIATAN SISWA UNTUK MENINGKATKAN KEMAMPUAN NUMBER SENSE SISWA
}

\author{
Nourma Pramestie Wulandari ${ }^{1}$, Anis Suraida Safitri ${ }^{2 *}$, Ratih Ayu Apsari ${ }^{1}$, Junaidi ${ }^{1}$, Ulfa \\ Lu'luilmaknun' ${ }^{1}$ \\ Program Studi Pendidikan Matematika, FKIP, Universitas Mataram ${ }^{1}$ \\ MA Al Mahrusiyah ${ }^{2}$ \\ *Email: anisss180493@gmail.com
}

\begin{abstract}
Abstrak
Number sense merupakan suatu rasa intuitif seseorang untuk dapat menaksir bilangan, mampu mendeteksi kesalahan dalam suatu perhitungan, dan teliti dalam menghitung. Number sense yang baik diperlukan sebagai faktor penunjang aktivitas sehari-hari. Number sense tidak hanya dalam mengenal tetapi juga terampil dalam berhitung. Hasil studi pendahuluan menunjukkan bahwa siswa belum peka terhadap keteraturan bilangan beserta operasinya, sehingga komponen number sense tentang pemahaman dan keterampilan mengenai bilangan juga kurang. Tujuan dari penelitian ini adalah untuk menghasilkan Lembar Kegiatan Siswa (LKS) dengan pendekatan kontekstual pada materi bilangan untuk meningkatkan kemampuan number sense yang valid. Lembar Kegiatan Siswa (LKS) ini ditujukan kepada siswa SMP Kelas VII. Pengembangan LKS ini dilakukan berdasarkan pada model Plomp (preliminary research, prototyping phase, and assessment phase). Kualitas produk yang dikembangkan mengacu pada bukti validitas isi. Validator terdiri dari 2 dosen Pendidikan Matematika. Bukti validitas LKS menunjukkan skor sebesar 3,395 dengan kategori valid dan tidak perlu direvisi. Namun untuk lebih menyempurnakan produk, revisi tetap dilakukan berdasarkan saran dan komentar validator. Oleh karena itu, dapat disimpulkan bahwa LKS layak untuk digunakan dalam pembelajaran matematika pada materi bilangan.
\end{abstract}

Kata Kunci : Bilangan, Kepekaan Bilangan, Lembar Kegiatan Siswa, Number Sense.

\begin{abstract}
Number sensi is a person's intuitive to estimate numbers, detect errors in a calculation, and be careful in calculating. A good number sense is needed as a supporting factor for daily activities. Number sense is not only about knowing number but also counting skill. The result of the preliminary study showed that the students were not sensitive to the regularity of numbers and their operations. It implies, the students' understanding and skills about numbers are poor. The aim of this research is to develop the student worksheets with a contextual approach to improve number sense ability. This student worksheets were intended for Grade VII Middle School students. This worksheet development was based on the Plomp model (preliminary research, prototyping phase, and assessment phase). The quality of the developed product was refering to the proof of content validity. The vaidators were two mathematics lecturers. The results of the students' worksheet validity from experts' judgment showed a score of 3.395. It means the worksheet is in valid category and need no revision. However, to improve the product, revisions are made based on the experts' suggestions and comments. Therefore, it can be concluded that the worksheet is feasible to be used in learning mathematics in number material.
\end{abstract}

Key Words : Numbers, Number Sense, Number Sense Ability, Student Worksheets.

\section{PENDAHULUAN}

Seiring perkembangan zaman, pembelajaran matematika diarahkan kepada ranah yang dapat membantu siswa untuk menyelesaikan masalah dalam kehidupan sehari-hari. Dalam matematika sekolah, khususnya pada jenjang SMP sudah menerapkan pembelajaran yang dapat membantu meningkatkan kemampuan menyelesaikan masalah matematika siswa. Pada kurikulum sekolah saat ini, pembelajaran yang dianjurkan adalah pembelajaran yang berpusat pada siswa. Siswa perlu diberikan kesempatan sebanyak-banyaknya untuk mandiri dalam berusaha memecahkan masalah [1]. 
Sehingga kedepannya siswa tidak hanya handal dalam berhitung, tetapi juga handal dalam menerapkan pengetahuan akan materi matematika yang telah dipelajari ke dalam berbagai situasi yang dialami [2].

Hal mendasar yang perlu dikuasai siswa dalam mempelajari matematika yakni memahami materi bilangan. Pemahaman yang dimaksud tidak hanya sekedar mengenal dan terampil dalam berhitung, akan tetapi dapat memiliki kepekaan terhadap bilangan (number sense). Kepekaan bilangan yang dimaksud yakni dapat memahami sifat-sifat bilangan beserta operasinya, memiliki fleksibilitas, dan intuisi yang baik dalam melakukan proses perhitungan mental [3], [4], [5]. Siswa dapat terbantu dengan perhitungan mental ini. Cara pandang siswa terhadap matematika yang hanya sebagai pelajaran di sekolah dapat berubah menjadi cara berpikir untuk memecahkan masalah sehari-hari [6].

Menurut McIntosh, Reys, \& Reys [7] number sense merupakan suatu rasa intuitif seseorang untuk dapat menaksir bilangan, mampu mendeteksi kesalahan serta mengenali hasil yang layak dalam suatu perhitungan, dan teliti serta efisien dalam menghitung. Dengan kata lain, siswa dengan kemampuan number sense yang baik memiliki intuisi yang baik terhadap bilangan [3]. Siswa tidak hanya terampil mengenai bilangan dan operasinya tetapi juga dapat memanfaatkan pengetahuannya antar konsep bilangan pada berbagai bidang dan situasi dalam kehidupannya. Sehingga masalah yang diberikan dapat terselesaikan dengan cara yang kreatif, efektif, praktis, dan efisien [8]. Faktanya, berdasarkan beberapa hasil penelitian, kemampuan number sense siswa di Indonesia masih tergolong rendah [9], [10], [11].

Pembelajaran di kelas hendaknya tidak selalu menjadikan guru sebagai fokus pemberi informasi. Siswa dapat termotivasi dan dapat secara langsung "mengalami”" apa yang dipelajari. Sehingga pembelajaran akan lebih efektif dan bermakna karena mampu membangun sendiri pengetahuannya [2]. Dalam hal ini, guru sebagai ujung tombak pembelajaran diharapkan untuk selalu kreatif dan berinovasi dalam mendesain pembelajaran demi meningkatkan keberhasilan siswa dalam belajar [12], [13]. Salah satu cara yang dapat dilakukan yakni dengan mengembangkan suatu media pembelajaran yang berupa Lembar Kegiatan Siswa (LKS) dengan memperhatikan karakteristik siswa berorientasi siswa aktif [14]. Selain itu, LKS yang dikembangkan dalam penerapannya menggunakan pendekatan kontektual sehingga dapat mengaitkan dengan situasi nyata dalam kehidupan sehari-hari [12], [13], [15].

LKS umumnya dikenal sebagai suatu bahan cetak berupa lembar-lembar kertas yang berisi materi, ringkasan, dan petunjukpetunjuk pelaksanaan kegiatan pembelajaran yang harus dicapai [16]. Struktur lembar kegiatan siswa secara umum terdiri dari judul LKS, mata pelajaran, semester, tempat, petunjuk belajar, kompetensi yang akan dicapai, indikator yang akan dicapai oleh siswa, informasi pendukung, tugas-tugas dan langkah-langkah kerja serta penilaian [17].

Berdasarkan hasil wawancara dengan dua guru matematika di SMP Wahidiyah diperoleh data, yaitu (1) pembelajaran menggunakan buku dari pemerintah dan didampingi dengan LKS yang dikembangkan oleh MGMP; (2) siswa cenderung lebih menyukai belajar menggunakan LKS daripada buku karena lebih ringkas dan tidak terlalu banyak katakata, (3) LKS yang dikembangkan tidak memuat terapan materi berupa fakta yang terjadi di lapangan, belum dapat mendorong siswa untuk memecahkan masalah, hal ini 
disebabkan isi LKS cenderung disajikan dalam bentuk sudah tersusun secara final; (4) LKS yang digunakan masih sederhana, tidak ada gambar dapat menarik perhatian siswa. Wina [18] menyatakan bahwa terkadang pengarang kurang memikirkan bagaimana produk tersebut agar mudah dipahami oleh siswa, teori dan desain suatu produk sama sekali tidak diaplikasikan. Sehingga perlu adanya produk LKS yang disusun secara sistematis dan dapat meningkatkan motivasi siswa untuk belajar matematika serta memfasilitasi siswa untuk belajar dengan baik.

Beberapa peneliti juga telah mengembangkan LKS (Lembar Kerja/Kegiatan Siswa) pada berbagai jenjang sekolah. Agustine, Apriani, dan Juniati [19] telah mengembangkan suatu produk bahan ajar berupa prototipe 1 Lembar Kerja Siswa (LKS) pada materi operasi hitung bilangan bulat untuk siswa kelas IV Sekolah Dasar. Yulia, Buyung, dan Relawati [20] telah mengembangkan produk Lembar Kerja Siswa (LKS) matematika pada materi angka untuk SMP kelas VII dengan model pembelajaran berbasis masalah. Purnamasari, Syaifudin, Muslimin [21] mengembangkan Lembar Kerja Siswa (LKS) berbasis pendekatan open- ended pada materi pecahan kelas VII SMP. Dari beberapa penelitian yang telah diuraikan, bahwa masih sedikitnya pengembangan LKS yang bertujuan untuk meningkatkan kemampuan number sense siswa. Berdasarkan seluruh paparan dan penelitian sebelumnya, maka tujuan penelitian ini menghasilkan suatu lembar kerja siswa materi bilangan dengan pendekatan kontekstual untuk meningkatkan kemampuan number sense siswa yang valid.

\section{METODE}

Penelitian ini merupakan penelitian pengembangan yang bertujuan untuk menghasilkan Lembar Kegiatan Siswa
(LKS) dengan pendekatan kontekstual pada materi bilangan untuk meningkatkan kemampuan number sense. Pengembangan yang dilakukan terdiri atas tiga fase, yakni penelitian awal (preliminary research), tahap pengembangan (prototype phase), tahap asesmen (assessment phase) [22].

Setelah keseluruhan tahap pengembangan LKS dilaksanakan, kemudian dilanjutkan dengan mendapatkan bukti validitas untuk menilai kelayakan LKS yang dikembangkan [23]. Data validasi terbagi atas dua jenis, yaitu data kuantitatif dan kualitatif. Data kuantitatif berupa nilai ratarata yang diperoleh berdasarkan penskoran lembar validasi LKS oleh validator. Sedangkan data kualitatif berupa komentar dan saran dari validator. Kegiatan validasi dilakukan dengan menyerahkan LKS dan instrumen validasi kepada validator yang terdiri dari dua ahli. Saran dan komentar digunakan sebagai landasan penyempurnaan atau revisi LKS.

Instrumen validasi terdiri atas 19 item pernyataan yang dibentuk berdasarkan 4 aspek penilaian pengembangan LKS. Aspek pertama mengenai kelayakan terdiri atas 6 item pernyataan, aspek kedua mengenai kesesuaian dengan pendekatan kontekstual terdiri atas 6 item pernyataan, aspek ketiga mengenai keterbacaan terdiri atas 3 item pernyataan, dan aspek keempat mengenai kegrafisan tediri atas 4 item pernyataan.

Nilai rata-rata indikator ditentukan berdasarkan pada hasil penilaian kevalidan LKS dari masing-masing validator. Validator terdiri dari 2 dosen pada bidang Pendidikan Matematika. Selanjutnya dilanjutkan dengan menentukan rata-rata untuk setiap aspek berdasarkan rata-rata nilai indikator. Rata-rata nilai untuk setiap aspek ditotal sehingga diperoleh nilai ratarata total aspek [24]. Selanjutnya nilai rata- 
rata total $\left(V_{a}\right)$ digunakan untuk menentukan hasil validasi sesuai dengan kriteria berikut.

Tabel 1. Kriteria Penentuan Hasil Validasi

\begin{tabular}{|c|c|c|}
\hline Interval & $\begin{array}{l}\text { Kriteria } \\
\text { Validitas }\end{array}$ & Keterangan \\
\hline $1 \leq V_{a}<1,75$ & Tidak valid & Revisi total \\
\hline $1,75 \leq V_{a}<2,5$ & Kurang valid & $\begin{array}{l}\text { Revisi } \\
\text { sebagian }\end{array}$ \\
\hline $2,5 \leq V_{a}<3,25$ & Cukup valid & $\begin{array}{l}\text { Revisi } \\
\text { sebagian }\end{array}$ \\
\hline $3,25 \leq V_{a}<4$ & Valid & $\begin{array}{l}\text { Tidak perlu } \\
\text { revisi }\end{array}$ \\
\hline$V_{a}=4$ & Sangat valid & $\begin{array}{l}\text { Tidak perlu } \\
\text { revisi }\end{array}$ \\
\hline
\end{tabular}

Keterangan: $V_{a}$ adalah penentuan tingkat kevalidan LKS

\section{HASIL DAN PEMBAHASAN}

Produk yang dikembangkan dalam penelitian ini adalah Lembar Kegiatan Siswa (LKS) materi bilangan dengan pendekatan kontekstual untuk meningkatkan kemampuan number sense siswa SMP kelas VII. Tampilan sampul depan dari LKS yang dikembangkan ditunjukkan pada Gambar 1. Gambar 2 merupakan contoh bagian dari isi LKS dengan memberikan masalah kontekstual untuk membelajarkan mengenai perkalian dan pembagian bilangan. Gambar 3 merupakan salah satu bagian dari isi LKS yang mengangkat masalah kontekstual untuk membahas mengenai materi bilangan pecahan.

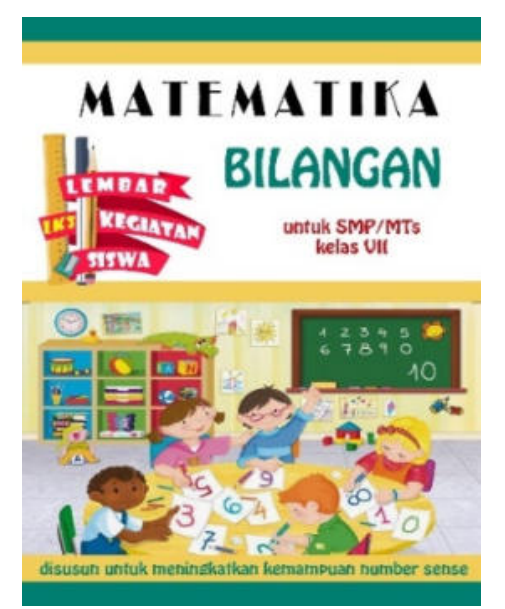

\section{Gambar 1. Sampul Depan LKS}

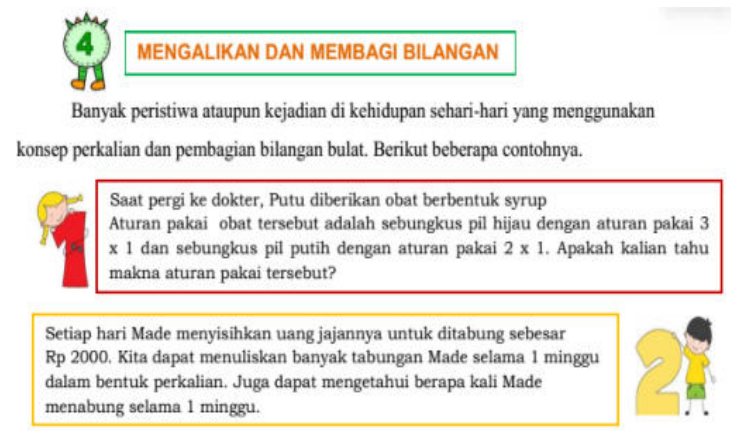
Gambar 2. Bagian Isi LKS pada Materi
Bilangan Pecahan

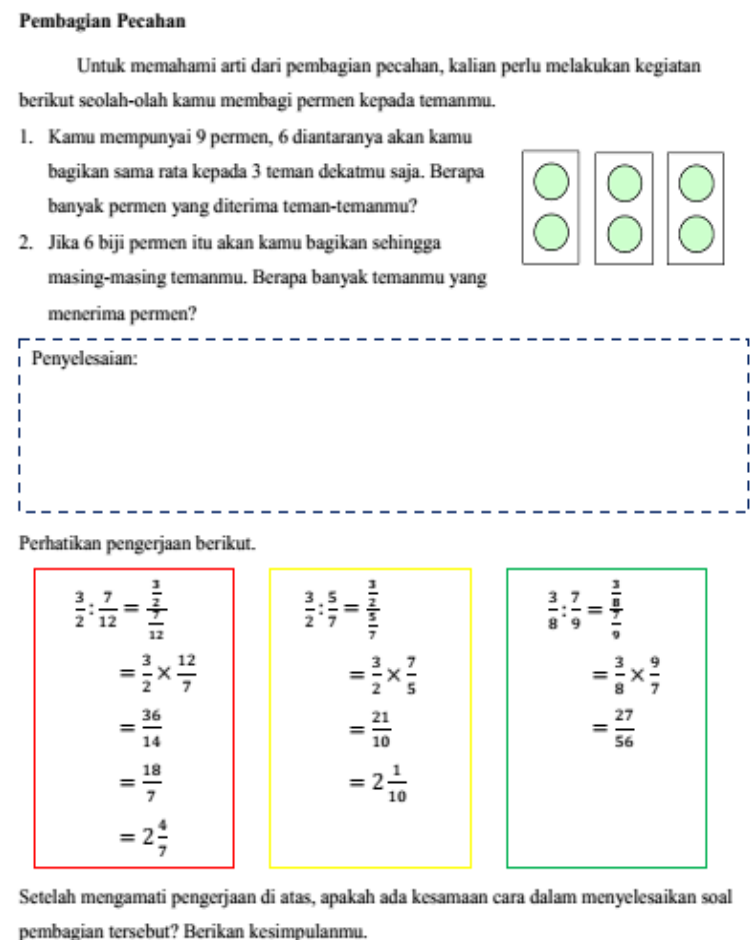




\section{Gambar 3. Bagian Isi LKS pada Materi Bilangan Pecahan}

Sedangkan hasil validasi yang diperoleh disajikan pada Tabel 2 dan Tabel 3.

\section{Tabel 2. Data Kuantitatif Hasil Validasi} Lembar Kegiatan Siswa

\begin{tabular}{llc}
\hline No. & \multicolumn{1}{c}{ Aspek yang dinilai } & $\begin{array}{c}\text { Rata-rata } \\
\text { skor }\end{array}$ \\
\hline 1. & Aspek Kelayakan Isi & 3,33 \\
2. & Aspek Kesesuaian dengan & 3,42 \\
& Pendekatan Kontekstual & 3,33 \\
3. & Aspek Keterbacaan & 3,5 \\
\hline
\end{tabular}

Tabel 3. Data Kualitatif Hasil Validasi Lembar Kegiatan Siswa

\begin{tabular}{ll}
\hline Validator 1 & Validator 2 \\
\hline Ganti atau hilangkan & Hindari menggunakan \\
penggunaan kata & kalimat yang susah \\
"coba" & dipamahi siswa \\
\hline
\end{tabular}

Berikut merupakan penjabaran data-data yang diperoleh berdasarkan penilaian ahli terhadap LKS.

- Aspek kelayakan isi memperoleh skor kevalidan 3,33 dengan kategori valid dan tidak perlu direvisi.

- Aspek kesesuaian dengan pendekatan kontekstual memperoleh skor kevalidan 3,42 dengan kategori valid dan tidak perlu direvisi.

- Aspek keterbacaan memperoleh skor kevalidan 3,33 dengan kategori valid dan tidak perlu direvisi.

- Aspek kegrafisan memperoleh skor kevalidan 3,5 dengan kategori valid dan tidak perlu direvisi.

Penilaian keseluruhan aspek dari dua validator terhadap LKS yang dikembangkan memperoleh skor kevalidan sebesar 3,395. Berdasarkan kriteria hasil kevalidan yang disajikan pada Tabel 1, maka dengan perolehan skor tersebut, LKS masuk pada kriteria valid. Sehingga tidak perlu dilakukan revisi. Selain praktis dan efektif, suatu produk dikatakan berkualitas jika memenuhi kriteria valid [23].

LKS yang dikembangkan telah memenuhi kriteria valid. Namun untuk lebih menyempurnakan LKS yang dikembangkan, maka tetap dilakukan revisi secara minor berdasarkan komentar dan saran dari validator. Perbaikan LKS dilakukan dengan menghilangkan kata "coba". Hal ini didasarkan pada pertimbangan bahwa kata tersebut dapat menyebabkan kalimat menjadi kurang efektif dan efisien. Tabel 4 menampilkan hasil revisi yang dilakukan pengembang.

\section{Tabel 4. Rincian Revisi yang Dilakukan}

\begin{tabular}{|c|c|}
\hline Halaman & Sebelum Revisi \\
\hline 2 & Coba ceritakan apa saja... \\
\hline 3 & $\begin{array}{l}\text { - Coba jelaskan apa yang } \\
\text { kamu... } \\
\text { - Coba jelaskan apa yang } \\
\text { kamu... }\end{array}$ \\
\hline 7 & $\begin{array}{l}\text { Coba sebutkan } 2 \text { penerapan } \\
\text { bilangan di... }\end{array}$ \\
\hline 8 & $\begin{array}{l}\text { - Coba lengkapilah garis } \\
\text { bilangan... } \\
\text { - Coba kelompokkan garis } \\
\text { bilangan... }\end{array}$ \\
\hline 10 & Coba bandingkan... \\
\hline 12 & $\begin{array}{l}\text { - Coba sebutkan } 2 \text { penerapan } \\
\text { konsep... } \\
\text { - Coba hitunglah... }\end{array}$ \\
\hline 15 & $\begin{array}{l}\text { Coba peragakan dan } \\
\text { selesaikan... }\end{array}$ \\
\hline 17 & $\begin{array}{l}\text { Coba kalian ingat kembali } \\
\text { sifat... }\end{array}$ \\
\hline 18 & $\begin{array}{l}\text { Coba sebutkan } 2 \text { penerapan } \\
\text { konsep pembagian... }\end{array}$ \\
\hline 19 & Coba tuliskan kesimpulan... \\
\hline 22 & $\begin{array}{l}\text { Coba berikan } 2 \text { ilustrasi } \\
\text { kejadian... }\end{array}$ \\
\hline 24 & $\begin{array}{l}\text { Coba tuliskan pecahan-pecahan } \\
\text { senilai... }\end{array}$ \\
\hline 32 & $\begin{array}{l}\text { Coba jelaskan dengan kata- } \\
\text { katamu sendiri... }\end{array}$ \\
\hline
\end{tabular}


34 Coba kamu lakukan kegiatan...

38 Coba ubahlah pecahan...

Agustine, Apriani, dan Juniati [19] telah mengembangkan suatu produk bahan ajar berupa prototipe 1 Lembar Kerja Siswa (LKS) pada materi operasi hitung bilangan bulat. Pengembangan LKS tersebut dikembangkan untuk untuk siswa kelas IV Sekolah Dasar. Dalam LKS tersebut menyajikan soal-soal dalam konteks seharihari (pendekatan kontekstual). Yulia, Buyung, dan Relawati [20] telah mengembangkan produk Lembar Kerja Siswa (LKS) matematika pada materi angka. LKS tersebut ditujukan untuk siswa SMP kelas VII. Konteks dalam LKS dikembangkan dengan model pembelajaran berbasis masalah. Purnamasari, Syaifudin, Muslimin [21] mengembangkan Lembar Kerja Siswa (LKS) pada materi pecahan. LKS ditujukan unutuk siswa kelas VII SMP. LKS dibuat berbasis pendekatan open- ended. Tujuan dikembangkannya LKS dari beberapa peneliti tersebut yaitu untuk meningkatkan hasil belajar siswa. Pada LKS yang dikembangkan peneliti bertujuan untuk meningkatkan kemampuan number sense siswa.

\section{SIMPULAN}

Lembar Kegiatan Siswa (LKS) yang dikembangkan layak untuk digunakan dalam pembelajaran matematika pada materi bilangan karena telah memenuhi kriteria valid dengan total skor 3,395 dan dengan keterangan tidak perlu direvisi. Namun dalam hal ini, pengembang tetap melakukan revisi secara minor dengan mempertimbangkan komentar serta saran yang diberikan oleh validator. Skor kevalidan tersebut diperoleh dari rata-rata skor pada aspek kelayakan isi, aspek kesesuaian dengan pendekatan kontekstual, aspek keterbacaan, dan aspek kegrafisan.

\section{DAFTAR PUSTAKA}

[1] H. D. Putra, T. Herman, and U. Sumarmo, "Development of Student Worksheets to Improve the Ability of Mathematical Problem Posing," Int. J. Emerg. Math. Educ., vol. 1, no. 1, p. 1, 2017, doi: 10.12928/ijeme.v1i1.5507.

[2] I. Kusmaryono, "keefektifan Pembelajaran Kontekstual Berorientasi Penemuan Berbantuan CD Pembelajaran dan LKS pada Materi Bilangan Bulat di Sekolah Dasar," Maj. Ilm. Sultan Agung, vol. 49, no. 123, pp. 1-18, 2011.

[3] C. Sa'dijah, "Kepekaan Bilangan Siswa SMP Melalui Pembelajaran Matematika Kontekstual Yang Mengintegrasikan Keterampilan Berpikir Kreatif," J. Pendidik. dan Pembelajaran Univ. Negeri Malang, vol. 20, no. 2, pp. 222-227, 2013.

[4] A. Yapici and M. Kayhan Altay, "An Investigation of Middle School Students' Number Sense Regarding The Percent," Abant İzet Baysal Üniversitesi Eğitim Fakültesi Derg., vol. 17, no. 4, pp. 2221-2243, 2017.

[5] S. Hadi, "Number sense : berpikir fleksibel dan intiusi tentang bilangan," Math Didact. J. Pendidik. Mat., vol. 1, no. 1, pp. 1-7, 2015.

[6] R. Akkaya, "An Investigation into the Number Sense Performance of Secondary School Students in Turkey," J. Educ. Train. Stud., vol. 4, no. 2, pp. 113-123, 2015, doi: 10.11114/jets.v4i2.1145.

[7] A. McIntosh, B. J. Reys, and R. E. Reys, "A Proposed Framework for Examining Basic Number Sense. For the learning of mathematics," Learn. Math., vol. 12, no. 3, pp. 2-8, 1992.

[8] D.-C. Yang and W.-R. Wu, "The study of number sense: Realistic 
activities integrated into third-grade math classes in Taiwan," J. Educ. Res., vol. 103, no. 6, pp. 379-392, 2010, doi: 10.1080/00220670903383010.

[9] Y. W. Purnomo, Kowiyah, F. Alyani, and S. S. Assiti, "Assessing number sense performance of Indonesian elementary school students," Int. Educ. Stud., vol. 7, no. 8, pp. 74-84, 2014, doi: 10.5539/ies.v7n8p74.

[10] R. Anggraini, A. Hartoyo, and Hamdani, "Kemampuan Number Sense Siswa Smp Negeri 5 Pontianak Dalam Menyelesaikan Soal Pada Materi Pecahan," J. Pendidik. dan Pembelajaran, vol. 4, no. 12, pp. 112, 2015.

[11] A. S. Safitri, S. Mulyati, and T. D. Chandra, "Kemampuan Number Sense Siswa Sekolah Menengah Pertama Kelas VII pada Materi Bilangan," in Prosiding SI MaNIs (Seminar Nasional Integrasi Matematika dan Nilai Islami), 2017, vol. 1, no. 1, pp. 270-277.

[12] Sumaji, "Pengembangan perangkat pembelajaran matematika dengan model pembelajaran pemecahan masalah untuk meningkatkan kemampuan penalaran matematis," in Prosiding Seminar Nasional Matematika dan Pendidikan Matematika UMS 2015, 2015, pp. 966-974.

[13] M. Khairani, "Efektivitas Modul Matematika Berbasis Kontekstual pada Materi Bilangan Pecahan," $J$. RESIDU, vol. 3, no. 24, pp. 69-77, 2019.

[14] I. Suryani, Y. Mardiati, and Y. Herlanti, "Pengaruh Penggunaan Lembar Kerja Siswa (LKS) Berbasis Kontekstual Terhadap Hasil Belajar Siswa pada Konsep Sistem gerak Manusia," EDUSAINS, vol. 8, no. 2, pp. 150-156, 2016, doi: /10.15408/es.v8i2.1823.
[15] S. Yulianti, "Pengaruh Penerapan Pendekatan CTL Terhadap Kemampuan Penalaran dan Komunikasi Matematika," Histogram J. Pendidik. Mat., vol. 3, no. 1, pp. 62-70, 2019, doi: 10.31100/histogram.v3i1.342.

[16] A. Prastowo, Panduan kreatif membuat bahan ajar inovatif. Yogyakarta: Diva Press, 2012.

[17] T. Widyantini, "Penyusunan Lembar Kegiatan Siswa (LKS) Sebagai Bahan Ajar," 2013.

[18] M. Wina, Strategi pembelajaran inovatif kontemporer suatu tinjauan operasional. Jakarta: Bumi Aksara, 2009.

[19] P. C. Agustine, F. Apriani, and I. Juniati, "Perancangan prototype LKS materi operasi hitung bilangan bulat untuk peserta didik Sekolah Dasar," J. Inov. Mat., vol. 1, no. 2, pp. 132 143, 2019, doi: 10.35438/inomatika.v1i2.150.

[20] S. Yulia, Buyung, and Relawati, "Pengembangan lembar kerja siswa (LKS) berbasis problem based learning pada materi bilangan di kelas VII SMP Negeri 22 Kota Jambi," PHI J. Pendidik. Mat., vol. 2, no. 1, pp. 61-70, 2018.

[21] E. Purnamasari, Syaifudin, and Muslimin, "Pengembangan Perangkat Pembelajaran Lembar Kegiatan Siswa Dengan Pendekatan Open-Ended Materi Bilangan Pecahan," UNION J. Pendidik. Mat., vol. 07, no. 01, pp. 23-36, 2019.

[22] T. Plomp and N. Nieveen, An introduction to educational design research. Enschede: Axis Mediaontwerpers, 2010.

[23] N. Nieveen, "Prototyping to Reach Product Quality," Des. Approaches Tools Educ. Training, Springer, pp. 125-135, 1999.

[24] Hobri, Metodologi Penelitian Pengembangan (Aplikasi pada 
Penelitian Pendidikan Matematika).

Jember: Pena Salsabila, 2010. 